\title{
MODERASI PARTISIPASI MASYARAKAT DAN TRANSPARANSI \\ KEBIJAKAN PUBLIK DALAM PENGARUH PENGETAHUAN \\ ANGGOTA DPRD TENTANG ANGGARAN TERHADAP \\ PENGAWASAN KEUANGAN DAERAH
}

\author{
Candra Winata \\ Dewi Amalia
}

\begin{abstract}
A change in the characteristics of the traditional budget to budget performance requires legislators to understand the changes. This causes the function of members of parlement to be very important in the process of preparation, approval, and oversight the budget. Independent variable are knowledge of local legislators about the budget. Dependent variable is local financial control. Moderating variable are public participation and public policy transparancy.Respondents in this study are legislative assembly at regency and city of Bima, Nusa Tenggara Barat Province. The data was collected by the survey. Data analysis techniques using simple linear regression and using moderated regression analysis. The result of this study indicated that first, knowledge of the legislators about the budget have effect to the local financial control. Second, public participation able to moderate the effect of participation in knowledge of legislators about the budget to the local financial control. Third, the transparency of public policy able to moderate the effect of knowledge of legislators about the budget to the local financial control.
\end{abstract}

Keywords: Knowledge of local legislators about the budget, local financial control, public participation, and public policy transparancy.

\section{PENDAHULUAN}

Undang-Undang Nomor 22 Tahun 1999 tentang Pemerintah Daerah pada prinsipnya, mengatur penyelenggaraan pemerintah daerah yang lebih mengutamakan pelaksanaan asas desentralisasi. Undang-Undang tersebut membuat adanya perubahan yang signifikan mengenai hubungan legislatif dan eksekutif di daerah karena kedua lembaga tersebut memiliki kekuatan yang sama dan bersifat sejajar menjadi mitra. Pasal 14 ayat (1) dinyatakan bahwa di daerah dibentuk DPRD sebagai Badan Legislatif Daerah dan Pemerintah Daerah sebagai Badan Eksekutif Daerah. Pemerintah Daerah yang dimaksud adalah Kepala Daerah beserta perangkat daerah lainnya. Dampak lain yang muncul dengan adanya otonomi daerah adalah tuntutan terhadap pemerintah dalam menciptakan good governance sebagai prasyarat dengan mengedepankan akuntabilitas dan transparansi. 
Anggaran merupakan suatu rencana kerja yang dinyatakan secara kuantitatif yang diukur dalam satuan moneter standar dan satuan ukuran yang lain yang mencakup jangka waktu satu tahun. Jenis anggaran yang akan dibahas dalam penelitian ini adalah APBD. Pengertian dari APBD dalam konteks Undang-Undang Nomor 17 Tahun 2003 pasal 1 ayat 8 tentang Keuangan Negara adalah suatu rencana keuangan tahunan daerah yang disetujui oleh DPRD. Adanya perubahan karakteristik dari traditional budget menjadi performance budget menuntut anggota DPRD untuk memahami perubahan tersebut. Pada anggaran tradisional, kepala daerah dianggap memiliki kinerja baik jika mereka dapat menghabiskan anggaran yang telah disediakan. Akan tetapi dengan adanya perubahan ke anggaran berbasis kinerja, Kepala Daerah memiliki kinerja yang baik jika besarnya anggaran yang digunakan setara dengan pelayanan yang diberikan kepada masyarakat (Erlina, 2008). Jadi, fungsi anggota DPRD sangatlah penting dalam proses penyusunan, pengesahan, dan pengawasan APBD.

Pramono (2002) manyebutkan pengawasan anggaran yang dilakukan oleh dewan dipengaruhi oleh faktor internal dan faktor eksternal. Pengawasan anggaran oleh DPRD dilakukan pada tahap perencanaan, pelaksanaan, dan pelaporan. DPRD memiliki kewenangan untuk menentukan arah dan kebijakan umum APBD. Apabila DPRD lemah pada tahap perencanaan yakni penentuan arah dan kebijakan umum APBD, maka sangat mungkin pada tahap pelaksanaan mengalami banyak penyimpangan. Pengawasan anggota DPRD terhadap eksekutif daerah adalah pengawasan terhadap pelaksanaan kebijakan yang digariskan, bukan pemeriksaan (Mardiasmo, 2002: 214).

Usaha menciptakan akuntabilitas kepada publik diperlukan partisipasi Kepala Instansi dan warga masyarakat dalam penyusunan dan pengawasan anggaran (Rubin, 1996 dalam Rosseptalia, 2006). Partisipasi masyarakat dapat diwujudkan dengan menjaring aspirasi masyarakat, maka kepala daerah harus dapat membuat skala prioritas kebutuhan masyarakat bukan daftar keinginan masyarakat (Erlina, 2008). Jadi semakin transparan kebijakan publik (APBD), maka pengawasan yang dilakukan oleh anggota DPRD akan semakin meningkat karena masyarakat juga terlibat dalam mengawasi kebijakan publik tersebut. 
Penelitian sejenis pernah dilakukan oleh Andriani (2002) yang menyatakan bahwa pengetahuan anggaran berpengaruh secara signifikan terhadap pengawasan keuangan daerah yang dilakukan oleh dewan. Sementara Pramono (2002) menyebutkan bahwa faktor-faktor yang menunjang fungsi pengawasan adalah adanya reformasi dan legitimasi wakil rakyat. Sedangkan faktor yang menghambat fungsi pengawasan adalah minimnya kualitas sumberdaya manusia serta kurangnya sarana dan prasarana.

Hasil penelitian Sopanah dan Mardiasmo (2003) menunjukkan bahwa pengetahuan anggota DPRD tentang anggaran berpengaruh signifikan terhadap pengawasan APBD yang dilakukan oleh dewan. Penelitian Erlina (2008) menunjukkan hasil bahwa latar belakang pendidikan dan jenjang pendidikan tidak mempunyai hubungan dengan pengawasan anggaran, tetapi pengetahuan tentang anggaran signifikansi mempengaruhi pengawasan anggaran yang dilakukan anggota dewan.

Penelitian ini dilakukan di Indonesia bagian Tengah dan baru beberapa tahun mengalami pemekaran, tepatnya di Kabupaten dan Kota Bima Provinsi Nusa Tenggara Barat. Daerah tersebut baru beberapa tahun mengalami pemekaran sehingga Dana Alokasi Umum (DAU) yang diterima oleh daerah tersebut tergolong besar, karena daerah tersebut masih dalam tahap pembangunan. DAU Kabupaten Bima pada tahun 2011 sebesar Rp515.830.730.000, sedangkan untuk DAU Kota Bima sebesar Rp268.001.565.000. Jumlah tersebut jauh lebih besar bila dibandingkan pada awal daerah tersebut mengalami pemekaran yakni untuk DAU Kabupaten Bima pada tahun 2004 sebesar Rp195.496.810.000, sedangkan untuk DAU Kota Bima sebesar Rp91.453.130.000. Jadi, peneliti tertarik untuk meneliti tentang pengawasan keuangan daerah yang dilakukan oleh anggota DPRD terhadap dana yang cukup besar tersebut. Berdasar permasalahan yang ada, peneliti tertarik untuk meneliti mengenai moderasi partisipasi masyarakat dan transparansi kebijakan publik dalam pengaruh pengetahuan anggota DPRD tentang anggaran terhadap pengawasan keuangan daerah 


\section{TINJAUAN PUSTAKA DAN PENGEMBANGAN HIPOTESIS}

\section{Pengertian Keuangan Daerah}

Menurut Baswir (1999) dalam Sopanah dan Mardiasmo (2003) pengertian keuangan negara adalah semua hak dan kewajiban negara serta segala sesuatu yang berkaitan dengan hak dan kewajiban tersebut yang dapat dinilai dengan uang. Pasal 1 Peraturan Pemerintah Nomor 105 Tahun 2000 pengertian keuangan daerah adalah semua hak dan kewajiban daerah dalam kerangka penyelenggaraan pemerintahan yang dapat dinilai dengan uang termasuk didalamnya segala bentuk kekayaan yang berhubungan dengan hak dan kewajiban daerah tersebut, dalam kerangka Anggaran Pendapatan dan Belanja Daerah. APBD adalah suatu rencana keuangan tahunan daerah yang ditetapkan berdasarkan peraturan daerah. Pemegang kekuasaan umum pengelolaan keuangan daerah adalah kepala daerah yang karena jabatannya mempunyai kewenangan menyelenggarakan keseluruhan pengelolaan keuangan daerah dan mempunyai kewajiban menyampaikan pertanggungjawaban atas pelaksanaan kewenangan tersebut kepada DPRD.

Anggaran merupakan rencana yang diungkapkan secara kuantitatif, biasanya dalam unit moneter (Halim et al., 2000 dalam Rosseptalia 2006). Menurut Anthony dan Govindarajan (2000: 3), proses penyusunan anggaran pada dasarnya memiliki 4 tujuan utama yaitu: (1) Menyelaraskan dengan rencana strategik, (2) Mengkoordinasikan kegiatan dari beberapa bagian dalam organisasi, (3) Memberikan tanggung jawab kepada manajer atau pimpinan, guna mengotorisasi jumlah dana yang dapat digunakan, dan untuk memberitahukan hasil yang mereka capai, dan (4) Mencapai kerjasama.

Anggaran sektor publik dibuat untuk membantu menentukan tingkat kebutuhan masyarakat agar terjamin secara layak. Penyusunan anggaran di dalam institusi publik berkaitan dengan proses penentuan alokasi jumlah dana untuk tiap program dan aktivitas pemerintah dalam satuan moneter. Proses penyusunan anggaran menjadi sangat penting karena anggaran yang tidak efektif dan tidak berorientasi pada kinerja akan dapat menggagalkan perencanaan atau strategi yang sudah disusun. Anggaran merupakan managerial plan for action untuk memfasilitasi tercapainya tujuan organisasi (Mardiasmo, 2002: 62). Aspek-aspek 
yang harus tercakup dalam anggaran sektor publik meliputi aspek perencanaan, aspek pengendalian, dan aspek akuntabilitas publik.

\section{Pengetahuan Anggota DPRD tentang Anggaran}

Salim (1991) dalam Sopanah dan Mardiasmo (2003) mengartikan pengetahuan sebagai kepandaian yaitu segala sesuatu yang diketahui dan sesuatu yang diketahui tersebut berkenan dengan sesuatu yang dipelajari. Pengetahuan erat kaitannya dengan pendidikan dan pengalaman. Ketiganya mempengaruhi seseorang dalam melakukan suatu tindakan. Pengalaman dan pengetahuan yang tinggi akan sangat membantu seseorang dalam memecahkan persoalan yang dihadapinya sesuai dengan kedudukan anggota DPRD sebagai wakil rakyat (Truman, 1960 dalam Werimon, 2005).

Posisi anggota DPRD sebagai badan legislatif menuntut pengetahuan dan kemampuan pemahaman tugasnya sebagai wakil rakyat, yang telah dipilih secara langsung oleh rakyat untuk mewujudkan masyarakat yang sejahtera. Oleh karena itu, anggota DPRD harus didukung dengan pendidikan dan pengalaman yang memadai dalam perencanaan dan perumusan kebijakan yang strategis yang berhubungan dengan keberhasilan daerah dalam pembangunan, sehingga dapat meningkatkan fungsi yang dimilikinya (Arifin, 2006 dalam Iswahyana, 2008).

\section{Partisipasi Masyarakat}

Partisipasi masyarakat adalah adanya masyarakat dalam proses pengambilan keputusan, kontribusi terhadap upaya pembagunan, dan pemanfaatan hasil-hasil pembangunan. Konsep partisipasi mengandung arti yang amat dalam dan sangat luas dalam hal informasi, perencanaan pembangunan, pelaksanaan pembangunan, penerimaan kembali hasil pembangunan, dan penilaian pembangunan. Partisipasi juga berfungsi menumbuhkan kemampuan masyarakat untuk berkembang secara mandiri (Priyadi, 2007 dalam Iswahyana, 2008).

Achmadi dkk. (2002) dalam Sopanah dan Mardiasmo (2003) menyebutkan bahwa partisipasi merupakan kunci sukses dari pelaksanaan otonomi daerah karena dalam partisipasi menyangkut aspek pengawasan dan aspirasi. Pengawasan yang dimaksud di sini termasuk pengawasan terhadap pihak eksekutif melalui pihak 
legislatif. Menurut Anthony dan Govindarajan (2003: 15) partisipasi di dalam penyusunan anggaran mempunyai efek yang positif, dengan alasan:

1. Ada penerimaan yang lebih besar dari tujuan anggaran jika mereka merasa berada dalam kontrol manajer, dibandingkan dengan adanya paksaan dari luar. Hal ini menuju kepada tanggung jawab individu untuk mencapai tujuan.

2. Hasil partisipasi pembuatan anggaran adalah pertukaran informasi yang efektif. Besarnya anggaran yang telah disetujui merupakan hasil kesepakatan antara ahli dan pembuat anggaran atau penyusun anggaran.

Partisipasi menjadi kunci sukses bagi pelaksanaan otonomi daerah karena di dalamnya menyangkut aspek pengawasan dan aspirasi, semakin aktif masyarakat dalam proses penyelenggaraan pemerintahan berarti semakin sukses pelaksanaan otonomi daerah. Namun kenyataan di lapangan tidak selalu masyarakat berpartisipasi secara aktif dalam proses penyelenggaraan pemerintah khususnya pada saat penyusunan anggaran (APBD).

\section{Transparansi Kebijakan Publik}

Selain adanya partisipasi masyarakat dalam siklus anggaran, transparansi anggaran juga diperlukan untuk meningkatkan pengawasan, karena transparansi merupakan salah satu prinsip dari good governance. Transparansi dibangun atas dasar arus informasi yang bebas, seluruh proses pemerintahan, lembaga-lembaga, dan informasi perlu dapat diakses oleh pihak-pihak yang berkepentingan, serta informasi yang tersedia harus memadai agar dapat dimengerti dan dipantau (Sopanah dan Mardiasmo, 2003).

Mengacu pada Peraturan Pemerintah Nomor 56 Tahun 2005 yang diperbaharui dengan Peraturan Pemerintah Nomor 65 Tahun 2010 tentang Sistem Informasi Keuangan Daerah, transparansi kebijakan khususnya kebijakan dalam penyusunan anggaran yang dibuat oleh pemerintah merupakan variabel penting yang menentukan keberhasilan pelaksanaan anggaran. Sopanah dan Mardiasmo (2003) menyatakan anggaran yang disusun oleh pihak eksekutif dikatakan transparansi jika memenuhi beberapa kriteria berikut:

1) Terdapat pengumuman kebijakan anggaran.

2) Tersedia dokumen anggaran dan mudah diakses. 
3) Tersedia laporan pertanggungjawaban yang tepat waktu.

4) Terakomodasinya suara/ usulan rakyat.

5) Terdapat sistem pemberian informasi kepada pubik.

\section{Pengawasan Keuangan Daerah}

Pengawasan merupakan tahap integral dengan keseluruhan tahap pada penyusunan dan pelaporan APBD. Pengawasan diperlukan pada setiap tahap bukan hanya pada tahap evaluasi saja (Mardiasmo, 2002: 214). Pengawasan yang dilakukan oleh dewan dimulai pada saat proses penyusunan APBD, pengesahan APBD, pelaksanaan APBD, dan pertanggungjawaban APBD. Pengawasan yang dilakukan oleh DPRD terhadap eksekutif dimaksudkan agar terdapat jaminan terciptanya pola pengelolaan anggaran daerah yang terhindar dari praktik Kolusi, Korupsi, dan Nepotisme (KKN) baik mulai dari proses perencanaan, pengesahaan, pelaksanaan, serta pertanggungjawabannya. Selain DPRD mengawasi secara langsung tentang mekanisme anggaran, terdapat aparat pengawasan eksternal pemerintah yang independen terhadap lembaga eksekutif di daerah yaitu Badan Pemeriksa Keuangan (Werimon, 2005).

\section{Rerangka Penelitian}

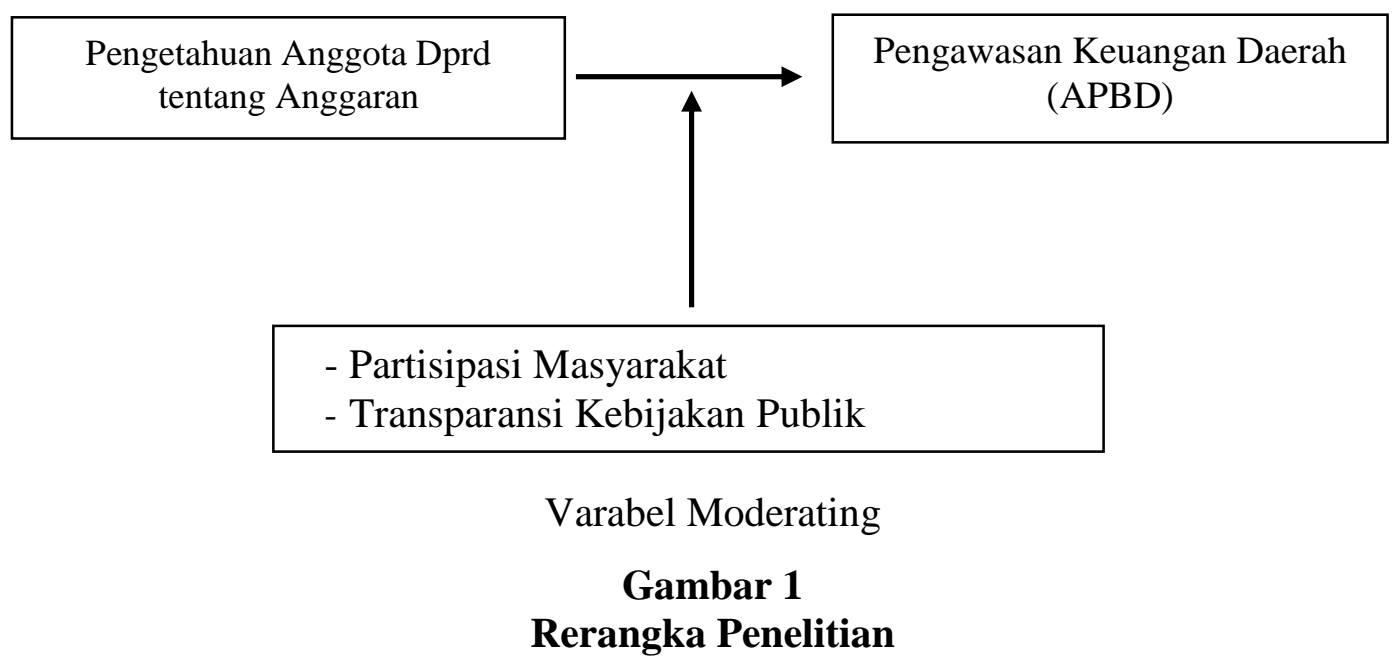




\section{Pengetahuan Anggota DPRD tentang Anggaran dan Pengawasan Keuangan Daerah}

Saat menjalankan fungsi dan peran anggota DPRD, kapasitas, dan posisi dewan sangat ditentukan oleh kemampuan bargaining position dalam memproduk sebuah kebijakan. Kapabilitas dan kemampuan dewan yang harus dimiliki antara lain pengetahuan, keterampilan dan pengalaman dalam menyusun berbagai peraturan daerah selain kepiawaian dewan dalam berpolitik mewakili konstituen dan kepentingan kelompok dan partainya (Sopanah dan Mardiasmo, 2003).

Beberapa penelitian yang menguji hubungan antara kualitas anggota dewan dengan kinerjanya diantaranya dilakukan oleh Indradi (2001), Syamsiar (2001), dan Sutarnoto (2002) dalam Erlina (2008). Hasil penelitiannya membuktikan bahwa kualitas dewan yang diukur dengan pendidikan, pengetahuan, pengalaman, dan keahlian berpengaruh terhadap kinerja dewan yang salah satunya adalah kinerja pada saat melakukan fungsi pengawasan. Pengetahuan yang dibutuhkan dalam melakukan pengawasan keuangan daerah salah satunya adalah pengetahuan tentang anggaran.

$\mathrm{H}_{1}$ : Pengetahuan anggota DPRD tentang anggaran berpengaruh terhadap pengawasan keuangan daerah di Kabupaten dan Kota Bima NTB.

\section{Partisipasi Masyarakat dan Pengawasan Keuangan Daerah}

Perubahan paradigma anggaran di era reformasi menuntut adanya partisipasi masyarakat (publik) dalam keseluruhan siklus anggaran. Usaha menciptakan akuntabilitas kepada publik diperlukan partisipasi kepala instansi dan warga masyarakat dalam penyusunan dan pengawasan anggaran (Rubin, 1996 dalam Sopanah dan Mardiasmo, 2003).

Beberapa penelitian yang menguji kemampuan partisipasi masyarakat dalam memoderasi pengaruh pengetahuan dewan tentang anggaran terhadap pengawasan keuangan daerah, di antaranya dilakukan oleh Sopanah dan Mardiasmo (2003), Werimon (2005), Rosseptalia (2006), dan Erlina (2008). Hasil penelitiannya adalah partisipasi masyarakat secara signifikan mampu memoderasi pengaruh pengetahuan dewan tentang anggaran terhadap pengawasan keuangan daerah. 
Achmadi dkk. (2002) dalam Sopanah dan Mardiasmo (2003) menyebutkan bahwa partisipasi merupakan kunci sukses dari pelaksanaan otonomi daerah karena dalam partisipasi menyangkut aspek pengawasan dan aspirasi. Peranan dewan dalam melakukan pengawasan keuangan daerah akan dipengaruhi oleh keterlibatan masyarakat dalam advokasi anggaran. Jadi, selain pengetahuan tentang anggaran yang mempengaruhi pengawasan yang dilakukan oleh dewan, partisipasi masyarakat diharapkan akan meningkatkan fungsi pengawasan.

$\mathrm{H}_{2}$ : Partisipasi masyarakat mampu memoderasi pengaruh pengetahuan anggota DPRD tentang anggaran terhadap pengawasan keuangan daerah di Kabupaten dan Kota Bima NTB.

\section{Transparansi Kebijakan Publik dan Pengawasan Keuangan Daerah}

Transparansi dibangun atas dasar arus informasi yang bebas, seluruh proses pemerintahan, lembaga-lembaga, dan informasi perlu dapat diakses oleh pihakpihak yang berkepentingan, dan informasi yang tersedia harus memadai agar dapat dimengerti dan dipantau (Sopanah dan Mardiasmo, 2003). Mengacu pada apa yang disampaikan dalam Peraturan Pemerintah Nomor 65 Tahun 2010 tentang Sistem Informasi Keuangan Daerah, tampak bahwa transparansi kebijakan khususnya kebijakan dalam penyusunan anggaran yang dibuat oleh pemerintah merupakan variabel yang penting dalam menentukan keberhasilan pelaksanaan anggaran dalam rangka menuju pemerintahan yang baik.

Hasil penelitian yang Rosseptalia (2006) menyatakan bahwa transparansi kebijakan publik memiliki pengaruh yang positif dan signifikan pada pengaruh pengetahuan dewan tentang anggaran terhadap pengawasan keuangan daerah. Menurut asumsinya semakin transparan kebijakan publik yang dalam hal ini adalah APBD, maka pengawasan yang dilakukan oleh dewan akan semakin meningkat. Hal tersebut disebabkan oleh dilibatkannya masyarakat dalam mengawasi kebijakan publik tersebut.

H3: Transparansi kebijakan publik mampu memoderasi pengaruh pengetahuan anggota DPRD tentang anggaran terhadap pengawasan keuangan daerah di Kabupaten dan Kota Bima NTB. 


\section{METODA PENELITIAN}

\section{Populasi dan Sampel}

Populasi penelitian ini adalah seluruh anggota DPRD di Kabupaten Bima dan Kota Bima, Provinsi Nusa Tenggara Barat. Populasi berjumlah 65 orang, yang terdiri atas anggota DPRD Kabupaten Bima 40 orang dan anggota DPRD Kota Bima 25 orang. Teknik pengambilan sampel menggunakan metoda purposive sampling dengan kriteria anggota DPRD tersebut masih aktif menjadi anggota DPRD Kabupaten Bima \& Kota Bima pada tahun 2012. Pengumpulan data menggunakan survei yakni dengan menyebarkan kuesioner langsung ke sekretariat masing-masing daerah.

\section{Definisi Operasional dan Pengukuran Variabel Pengetahuan Anggota DPRD tentang Anggaran}

Pengetahuan adalah persepsi responden tentang anggaran (RAPBD/APBD) dan deteksi terhadap pemborosan atau kegagalan, dan kebocoran anggaran (Sopanah dan Mardiasmo, 2003). Peneliti menggunakan instrumen Rosseptalia (2006) yang menyebutkan bahwa indikator yang digunakan untuk mengukur variabel pengetahuan anggaran ini adalah:

a. Pengetahuan terhadap penyusunan APBD.

b. Pengetahuan terhadap pelaksanaan APBD.

c. Pengetahuan mendeteksi terjadinya kebocoran dalam pelaksanaan APBD.

d. Pengetahuan mendeteksi terjadinya pemborosan/kegagalan pelaksanaan APBD.

Variabel pengetahuan anggaran diukur dengan model 5 skala Likert. Semakin tinggi skor, artinya semakin besar pengaruh pengetahuan anggota DPRD tentang anggaran terhadap pengawasan keuangan daerah.

\section{Partisipasi Masyarakat}

Partisipasi masyarakat adalah keterlibatan masyarakat dalam setiap aktivitas proses penganggaran yang dilakukan oleh dewan pada saat penyusunan arah dan kebijakan, penentuan strategi, dan prioritas serta advokasi anggaran (Sopanah dan Mardiasmo, 2003). Penelitian ini menggunakan instrumen yang telah digunakan 
oleh Rosseptalia (2006) yang menyebutkan bahwa indikator yang digunakan untuk mengukur variabel partisipasi masyarakat ini adalah:

a. Dilibatkannya masyarakat untuk memberikan masukan dalam penyusunan arah dan kebijakan umum APBD.

b. Masukan dan kritik dari masyarakat terhadap prioritas dan rencana APBD.

c. Dilibatkannya masyarakat dalam penyusunan APBD.

d. Dilibatkannya masyarakat dalam advokasi APBD.

e. Dilibatkannya masyarakat dalam konsultasi dan konfirmasi antara dewan dan pemerintah daerah berkaitan dengan rancangan APBD.

f. Kritik \& saran masyarakat sebagai masukan dalam melakukan revisi APBD.

g. Pelaksanaan sosialisasi kepada masyarakat, jika terjadi perubahan kebijakan yang berkaitan dengan APBD.

Variabel ini diukur menggunakan 5 skala Likert. Semakin tinggi skor, artinya semakin besar kemampuan partisipasi masyarakat dalam memoderasi pengaruh pengetahuan anggota DPRD tentang anggaran terhadap pengawasan keuangan daerah (APBD).

\section{Transparansi Kebijakan Publik}

Transparansi kebijakan publik adalah adanya keterbukaan tentang anggaran yang mudah diakses oleh masyarakat (Sopanah dan Mardiasmo, 2003). Penelitian ini menggunakan instrumen yang telah digunakan oleh Rosseptalia (2006) yang menyebutkan bahwa indikator yang digunakan untuk mengukur variabel transparasi kebijakan publik ini adalah:

a. Pengumuman atau pemberian informasi oleh pemerintah daerah berkaitan dengan kebijakan anggaran yang telah disusun.

b. Kemudahan dokumen-dokumen kebijakan anggaran yang telah disusun oleh pemerintah daerah untuk diketahui publik.

c. Ketepatan waktu penyampaian laporan pertanggungjawaban.

d. Kemampuan transparansi anggaran dalam meningkatkan dan mengakomodasi usulan masyarakat.

e. Adanya sistem penyampaian informasi anggaran kepada publik. 
Variabel transparansi kebijakan publik diukur dengan model 5 skala Likert. Semakin tinggi skor, artinya semakin besar kemampuan transparansi kebijakan publik dalam memoderasi pengaruh pengetahuan anggota DPRD tentang anggaran terhadap pengawasan keuangan daerah (APBD).

\section{Pengawasan Keuangan Daerah}

Pengawasan keuangan daerah adalah pengawasan yang dilakukan oleh dewan yang meliputi pengawasan pada saat penyusunan, pengesahan, pelaksanaan, dan pertanggungjawaban anggaran. Penelitian ini menggunakan instrumen yang telah digunakan Rosseptalia (2006) yang menyebutkan bahwa indikator untuk mengukur variabel pengawasan keuangan daerah ini sebagai berikut:

a. Keterlibatan anggota DPRD dalam penyusunan arah \& kebijakan umum APBD.

b. Pelaksanaan analisis politik terhadap proses penyusunan APBD.

c. Keterlibatan anggota DPRD dalam pengesahan APBD.

d. Kemampuan menjelaskan APBD yang telah disusun.

e. Keyakinan anggota DPRD bahwa APBD telah memiliki transparansi.

f. Keterlibatan anggota DPRD dalam memantau pelaksanaan APBD.

g. Evaluasi yang dilakukan anggota DPRD terhadap laporan pertanggungjawaban.

h. Evaluasi yang dilakukan anggota DPRD terhadap faktor atau alasan yang mendorong timbulnya revisi APBD.

i. Permintaan keterangan oleh anggota DPRD terhadap laporan pertanggungjawaban APBD yang disampaikan Bupati/Walikota.

j. Tindak lanjut dari anggota DPRD jika terjadi kejanggalan dalam laporan pertanggungjawaban APBD.

Variabel pengawasan keuangan daerah diukur dengan model 5 skala Likert. Semakin tinggi skor, artinya semakin besar pengawasan yang dilakukan oleh anggota DPRD terhadap keuangan daerah (APBD).

\section{Pengujian Hipotesis}

Regresi linear sederhana digunakan untuk menguji hipotesis 1 dalam penelitian ini dengan persamaan berikut: 


$$
\mathbf{Y}=\mathbf{a}+\mathbf{b X}+\boldsymbol{e}
$$

Keterangan:

Y: $\quad$ Pengawasan keuangan daerah (APBD).

a: Konstanta.

b: $\quad$ Koefisien regresi.

$\mathrm{X}$ : Pengetahuan anggota DPRD tentang anggaran.

e: $\quad$ Error

Moderated regression analysis (MRA) digunakan untuk menguji hipotesis 2 dan hipotesis 3 penelitian ini. MRA merupakan aplikasi khusus regresi berganda linear yang dalam persamaan regresinya mengandung unsur moderasi (Ghozali, 2006: 200). Model persamaan MRA dalam penelitian ini adalah:

$$
\mathrm{Y}=\mathrm{a}+\mathrm{b} 1 \mathrm{X} 1+\mathrm{b} 2 \mathrm{X} 2+\mathrm{b} 3 \mathrm{X} 3+\mathrm{b}_{4} \mathrm{X} 1 \mathrm{X} 2+\mathrm{b}_{5} \mathrm{X} 1 \mathrm{X} 3+e
$$

Keterangan:

Y: $\quad$ Pengawasan keuangan daerah (APBD).

a: Konstanta.

b1-b5: Koefisien regresi.

X1: $\quad$ Pengetahuan anggota DPRD tentang anggaran.

X2: $\quad$ Partisipasi masyarakat.

X3: $\quad$ Transparansi kebijakan publik.

X1X2: $\quad$ Moderasi antara pengetahuan anggota DPRD tentang anggaran dan partisipasi masyarakat.

X1X3: $\quad$ Moderasi antara pengetahuan anggota DPRD tantang anggaran dan transparansi kebijakan publik.

e: $\quad$ Error. 
HASIL DAN PEMBAHASAN

Tabel 1

Demografi Responden

\begin{tabular}{|l|l|c|c|}
\hline \multicolumn{2}{|c|}{ Keterangan } & Frekuensi & Persentase \\
\hline Responden anggota & Kota Bima & 5 & $12 \%$ \\
DPRD & Kabupaten Bima & 36 & $88 \%$ \\
\hline \multirow{2}{*}{ Jenis kelamin } & Laki-laki & 39 & $95 \%$ \\
& Perempuan & 2 & $5 \%$ \\
\hline \multirow{3}{*}{ Usia } & 21-35 Tahun & 2 & $5 \%$ \\
& 36-45 Tahun & 10 & $71 \%$ \\
& $>$ 46 Tahun & 29 & $24 \%$ \\
\hline \multirow{3}{*}{ Pendidikan } & SLTA & 3 & $7 \%$ \\
& S1 & 31 & $76 \%$ \\
& S2 & 7 & $17 \%$ \\
\hline
\end{tabular}

Sumber: Data primer, diolah (2012).

Jumlah kuesioner yang disebar 65 buah, yang kembali 45 buah, dan yang dapat diolah dalam penelitian ini sebanyak 41 buah. Berdasar hasil pengukuran variabel pengetahuan anggota DPRD tentang anggaran pada tabel 2. skor jawaban responden berkisar antara 3,70 hingga 5,00 dengan rata-rata 4,70. Hal ini menunjukkan bahwa terdapat responden dalam penelitian ini yang mempunyai pengetahuan anggota DPRD tentang anggaran yang tergolong baik.

Tabel 2

Statistik Deskriptif Variabel Penelitian

\begin{tabular}{|l|c|c|c|c|c|}
\hline \multicolumn{1}{|c|}{ Variabel } & $\mathbf{N}$ & Minimum & Maksimum & $\begin{array}{c}\text { Rata- } \\
\text { rata }\end{array}$ & $\begin{array}{c}\text { Deviasi } \\
\text { Standar }\end{array}$ \\
\hline $\begin{array}{l}\text { Pengetahuan anggota } \\
\text { DPRD tentang } \\
\text { Anggaran (X1) }\end{array}$ & 41 & 3,70 & 5,00 & 4,70 & 0,32 \\
\hline $\begin{array}{l}\text { Partisipasi Masyarakat } \\
\left(\mathrm{X}_{2}\right)\end{array}$ & 41 & 4,00 & 5,00 & 4,94 & 0,19 \\
\hline $\begin{array}{l}\text { Transparansi } \\
\text { Kebijakan Publik }\left(\mathrm{X}_{3}\right)\end{array}$ & 41 & 3,43 & 5,00 & 4,60 & 0,42 \\
\hline $\begin{array}{l}\text { Pengawasan } \\
\text { Keuangan Daerah (Y) }\end{array}$ & 41 & 2,80 & 4,80 & 3,81 & 0,58 \\
\hline
\end{tabular}

Sumber: Data primer, diolah (2012). 


\section{Uji Kualitas Data}

Uji validitas dilakukan dengan metoda product moment Karl Pearson yaitu dengan melakukan korelasi bivariate antara masing-masing skor indikator dengan total skor konstruk. Instrumen dikatakan valid jika memiliki nilai Pearson correlation lebih besar dari nilai koefisien korelasi (Ghozali, 2006: 52). Berdasar tabel 3 diketahui bahwa semua memenuhi kriteria uji validitas.

Tabel 3

Hasil Uji Validitas Data

\begin{tabular}{|c|c|c|c|}
\hline \multicolumn{4}{|c|}{$\begin{array}{c}\text { Pengetahuan Anggota DPRD } \\
\text { tentang Anggaran }\end{array}$} \\
\hline No & $\begin{array}{c}\text { Pearson } \\
\text { correlation }\end{array}$ & $\begin{array}{c}\text { Nilai } \\
\text { koefisien } \\
\text { korelasi } \\
\text { (r) }\end{array}$ & Ket. \\
\hline 1 & 0,783 & 0,3081 & Valid \\
\hline 2 & 0,783 & 0,3081 & Valid \\
\hline 3 & 0,797 & 0,3081 & Valid \\
\hline 4 & 0,774 & 0,3081 & Valid \\
\hline
\end{tabular}

Pengawasan Keuangan Daerah (APBD)

\begin{tabular}{|c|c|c|c|}
\hline No & $\begin{array}{c}\text { Pearson } \\
\text { correlation }\end{array}$ & $\begin{array}{c}\text { Nilai } \\
\text { koefisien } \\
\text { korelasi } \\
(\mathrm{r})\end{array}$ & Ket. \\
\hline 1 & 0,410 & 0,3081 & Valid \\
\hline 2 & 0,618 & 0,3081 & Valid \\
\hline 3 & 0,670 & 0,3081 & Valid \\
\hline 4 & 0,700 & 0,3081 & Valid \\
\hline 5 & 0,451 & 0,3081 & Valid \\
\hline 6 & 0,675 & 0,3081 & Valid \\
\hline 7 & 0,711 & 0,3081 & Valid \\
\hline 8 & 0,638 & 0,3081 & Valid \\
\hline 9 & 0,764 & 0,3081 & Valid \\
\hline 10 & 0,746 & 0,3081 & Valid \\
\hline Sumb
\end{tabular}

\begin{tabular}{|c|c|c|c|}
\hline \multicolumn{4}{|c|}{ Partisipasi Masyarakat } \\
\hline No & $\begin{array}{c}\text { Pearson } \\
\text { correlation }\end{array}$ & $\begin{array}{c}\text { Nilai } \\
\text { koefisien } \\
\text { korelasi } \\
(\mathrm{r})\end{array}$ & Ket. \\
\hline 1 & 0,699 & 0,3081 & Valid \\
\hline 2 & 0,791 & 0,3081 & Valid \\
\hline 3 & 0,842 & 0,3081 & Valid \\
\hline 4 & 0,824 & 0,3081 & Valid \\
\hline 5 & 0,678 & 0,3081 & Valid \\
\hline 6 & 0,644 & 0,3081 & Valid \\
\hline 7 & 0,573 & 0,3081 & Valid \\
\hline \multicolumn{4}{|c|}{ Transparasi Kebijakan Publik } \\
\hline No & $\begin{array}{c}\text { Pearson } \\
\text { correlation }\end{array}$ & $\begin{array}{c}\text { Nilai } \\
\text { koefisien } \\
\text { korelasi } \\
(\mathrm{r}) \\
\end{array}$ & Ket. \\
\hline 1 & 0,445 & 0,3081 & Valid \\
\hline 2 & 0,809 & 0,3081 & Valid \\
\hline 3 & 0,799 & 0,3081 & Valid \\
\hline 4 & 0,524 & 0,3081 & Valid \\
\hline 5 & 0,558 & 0,3081 & Valid \\
\hline
\end{tabular}

Sumber: Data primer, diolah (2012). 
Pengujian selanjutnya yaitu uji reliabilitas menggunakan metoda Cronbach alpha. Berdasar hasil uji reliabilitas diperoleh nilai Cronbach alpha > 0,60, sehingga dapat disimpulkan bahwa kuesioner yang digunakan dalam penelitian ini reliabel. Jadi, kuesioner yang digunakan dalam penelitian ini secara statistika layak digunakan sebagai alat pengumpul data karena telah memenuhi validitas \& reliabilitas yang disyaratkan.

Tabel 4

Hasil Uji Reliabilitas Data

\begin{tabular}{|c|l|c|c|}
\hline No & \multicolumn{1}{|c|}{ Variabel } & $\begin{array}{c}\text { Cronbach } \\
\text { alpha }\end{array}$ & Keterangan \\
\hline 1 & Pengetahuan Anggota DPRD tentang Anggaran & 0,704 & Reliabel \\
\hline 2 & Partisipasi Masyarakat & 0,846 & Reliabel \\
\hline 3 & Transparasi Kebijakan Publik & 0,644 & Reliabel \\
\hline 4 & Pengawasan Keuangan Daerah (APBD) & 0,827 & Reliabel \\
\hline
\end{tabular}

Sumber: Data primer, diolah (2012).

\section{Analisis Regresi Berganda}

Pengujian hipotesis 1 dalam penelitian ini yakni dengan menggunakan uji t. Dasar pengambilan keputusan berdasar nilai probabilitas signifikansi. Jika nilai signifikansi < alpha, maka hipotesis 1 diterima. Hubungan yang ditunjukkan oleh koefisien regresi adalah positif $(0,781)$, artinya semakin tinggi pengetahuan anggota DPRD tentang anggaran maka pengawasan yang dilakukan akan semakin meningkat. Hasil penelitian ini mendukung penelitian yang Sopanah \& Mardiasmo (2003); Werimon (2005); Rosseptalia (2006); dan Erlina (2008).

Tabel 5

\section{Hasil Analisis Regresi Sederhana}

\begin{tabular}{|l|c|c|c|c|c|}
\hline \multicolumn{1}{|c|}{ Variabel } & $\begin{array}{c}\text { Unstandardized } \\
\text { Coefficients (B) }\end{array}$ & $\begin{array}{c}\text { Adjusted } \\
\mathbf{R}^{\mathbf{2}}\end{array}$ & Sig. & Alpha & Keputusan \\
\hline $\begin{array}{l}\text { Pengetahuan anggota } \\
\text { DPRD tentang } \\
\text { anggaran }\end{array}$ & 0,781 & 0,202 & 0,002 & 0,05 & $\begin{array}{c}\text { H1 } \\
\text { diterima }\end{array}$ \\
\hline
\end{tabular}

Sumber: Data primer, diolah (2012).

Indriantoro dan Supomo (1999: 6) menyatakan bahwa pengetahuan diperoleh dari pendidikan \& pengalaman. Pengetahuan yang dimiliki seseorang memberikan 
konstribusi yang lebih baik apabila didukung pendidikan \& pengalaman yang memadai untuk bidang tugasnya. Dengan demikian, pendidikan dan pengalaman memberikan dukungan kepada para anggota DPRD untuk meningkatkan kemampuan pengawasannya, terutama pengawasan terhadap APBD.

\section{Moderated Regression Analysis}

MRA digunakan untuk menguji hipotesis 2 dan hipotesis 3 dalam penelitian ini. Hasil pengujian hipotesis 2 menunjukkan hasil bahwa nilai signifikansi $(0,018)$ < alpha (0,05), maka hipotesis 2 diterima. Jadi, partisipasi masyarakat mampu memoderasi pengaruh pengetahuan anggota DPRD tentang anggaran terhadap pengawasan keuangan daerah. Hubungan yang ditunjukkan oleh koefisien regresi adalah negatif $(-2,727)$, artinya semakin besar partisipasi masyarakat, maka akan memperlemah pengaruh pengetahuan anggota DPRD tentang anggaran terhadap pengawasan keuangan daerah. Hasil penelitian ini konsisten dengan teori yang menyatakan bahwa persepsi antara satu individu dengan individu yang lainnya sangatlah mungkin memiliki perbedaan. Terdapat 3 faktor utama yang mempengaruhi persepsi, yaitu faktor dalam situasi, faktor pada pemersepsi, dan faktor pada target. Faktor dalam situasi meliputi: waktu, keadaan/ tempat kerja, dan keadaan sosial. Sedangkan faktor pada pemersepsi meliputi: sikap, motif, kepentingan, pengalaman, dan penghargaan (Robbins, 1987 dalam Werimon, 2005).

Tabel 6

Hasil Uji Moderated Regression Analysis

\begin{tabular}{|c|c|c|c|c|c|}
\hline Variabel & $\begin{array}{c}\text { Adjusted } \\
\mathbf{R}^{\mathbf{2}}\end{array}$ & $\begin{array}{c}\text { Unstandardized } \\
\text { Coefficients }\end{array}$ & Sig. & Alpha & Keputusan \\
\cline { 1 - 3 } $\begin{array}{c}\text { Moderasi } \\
\mathrm{X}_{1} \mathrm{X}_{2}\end{array}$ & \multirow{2}{*}{0,458} & $-2,727$ & 0,018 & \multirow{2}{*}{0,05} & H2 diterima \\
\cline { 1 - 3 } $\begin{array}{c}\text { Moderasi } \\
\mathrm{X}_{1} \mathrm{X}_{3}\end{array}$ & & $-2,657$ & 0,001 & & H3 diterima \\
\cline { 3 - 4 }
\end{tabular}

Sumber: Data primer, diolah (2012).

Hasil pengujian hipotesis 3 diperoleh nilai signifikansi $(0,001)<$ alpha $(0,05)$, maka hipotesis 3 diterima. Jadi, transparansi kebijakan publik mampu memoderasi pengaruh pengetahuan anggota DPRD tentang anggaran terhadap pengawasan 
keuangan daerah. Hubungan yang ditunjukkan oleh koefisien regresi adalah negatif $(-2,657)$ artinya semakin tinggi transparansi kebijakan publik, maka akan memperlemah pengaruh pengetahuan anggota DPRD tentang anggaran terhadap pengawasan keuangan daerah.

Sopanah dan Mardiasmo (2003) menyatakan transparansi dibangun atas dasar arus informasi yang bebas, seluruh proses pemerintahan, lembaga-lembaga, dan informasi perlu dapat diakses oleh pihak-pihak yang berkepentingan, dan informasi yang tersedia harus memadai agar dapat dimengerti dan dipantau. Jadi, semakin transparan suatu kebijakan (APBD), maka akan semakin banyak yang memantau/mengawasi kebijakan tersebut. Hal tersEbut akan memperlemah pengawasan keuangan daerah (APBD) yang dilakukan oleh anggota DPRD. Hal tersebut sesuai dengan yang dikemukakan oleh Robbins (1987) dalam Werimon (2005) yang menyatakan bahwa pengamatan perilaku seorang individu, didasarkan darimana perilaku itu timbul, secara internal atau eksternal.

\section{SIMPULAN DAN SARAN}

Pengetahuan anggota DPRD tentang anggaran berpengaruh terhadap pengawasan keuangan daerah di Kabupatan dan Kota Bima Provinsi Nusa Tenggara Barat. Partisipasi masyarakat mampu memoderasi pengaruh pengetahuan anggota DPRD tentang anggaran terhadap pengawasan keuangan daerah di Kabupatan dan Kota Bima Provinsi Nusa Tenggara Barat. Transparansi kebijakan publik mampu memoderasi pengaruh pengetahuan anggota DPRD tentang anggaran terhadap pengawasan keuangan daerah di Kabupaten dan Kota Bima Provinsi Nusa Tenggara Barat.

Keterbatasan dalam penelitian ini adalah sampel anggota DPRD yang diambil dari tingkat Kota dan Kabupaten, serta data hanya diperoleh dari anggota DPRD saja, tanpa melibatkan mahasiswa, LSM, maupun masyarakat. Selain itu, pada saat pengumpulan data yang menyebarkan kuesioner adalah sekretariat kantor DPRD, sehingga peneliti tidak bertemu langsung dengan responden.

Berdasar hasil penelitian, maka peneliti mengusulkan saran kepada anggota DPRD di Kabupatan dan Kota Bima Provinsi Nusa Tenggara Barat agar menjaga 
dan lebih meningkatkan pengetahuan tentang anggaran, sehingga dapat meningkatkan fungsi pengawasan keuangan daerah. Menjalin koordinasi yang baik antara DPRD dengan masyarakat dalam hal pengawasan keuangan daerah, agar anggota DPRD dapat menginterpretasikan aspirasi masyarakat. Melaksanakan fungsi pengawasan dengan lebih baik, dengan asumsi bahwa semakin transparan suatu kebijakan (APBD) maka semakin banyak pihak yang mengawasi.

\section{DAFTAR PUSTAKA}

Erlina. 2008. "Pengaruh Pengetahuan Dewan tentang Anggaran terhadap Pengawasan Keuangan Daerah dan Kinerja Dewan: Peranan Partisipasi Masyarakat di Sumatera Utara”. Jurnal Wawasan, Vol. 13(3), hal. 164172.

Ghozali, Imam. 2006.Aplikasi Analisis Multivariat dengan Program SPSS. Semarang: Badan Penerbit Universitas Diponegoro.

Govindarayan, Vijay, dan Robert N. Anthony. 2000. Sistem Pengendalian Manajemen. Jakarta: Salemba Empat.

Indrantoro, Nur, dan Bambang Supomo. 1999. Metodologi Penelitian Bisnis. Yogyakarta: BPFE UGM.

Iswahyana. 2008. "Pengaruh Pengetahuan Dewan tentang Anggaran terhadap Pengawasan Keuangan Daerah serta Partisipasi Masyarakat dan Transparansi Kebijakan Publik sebagai Variabel Moderating Studi pada Kota Pangkalpinang”. Skripsi. Yogyakarta: Universitas Ahmad Dahlan.

Mardiasmo. 2002. Akuntansi Sektor Publik. Yogyakarta: Andi.

Mardiasmo. 2002. Otonomi dan Manajemen Keuangan Daerah. Yogyakarta: Andi.

Republik Indonesia. 2004. Himpunan Undang-Undang Republik Indonesia. Jakarta, Indonesia.

Republik Indonesia. Keputusan MENDAGRI R.I No. 4 Tahun 1999 tentang Pokokpokok Kebijaksanaan Penyusunan Anggaran Pendapatan dan Belanja Daerah Tahun Anggaran 1999/2000. Jakarta, Indonesia. 
Republik Indonesia. 2005. Undang-Undang Republik Indonesia Nomor 22 Tahun 1999 tentang Pemerintah Daerah.Jakarta, Indonesia.

Republik Indonesia. 2005. Undang-Undang Republik Indonesia Nomor 33 Tahun 2004 tentang Perimbangan Keuangan antara Pemerintah Pusat dan Pemerintah Daerah. Jakarta, Indonesia.

Republik Indonesia. 2005. Undang-Undang Republik Indonesia Nomor 56 Tahun 2005 tentang Sistem Informasi Keuangan Daerah. Jakarta, Indonesia.

Republik Indonesia. 2004. Undang-Undang Otonomi Daerah. Jakarta, Indonesia.

Republik Indonesia. 2001. Peraturan Pemerintah Nomor 105 Tahun 1999 tentang Pengelolaan dan Pertanggungjawaban Anggaran. Jakarta, Indonesia.

Republik Indonesia. 1998. Ketetapan MPR Nomor XV/MPR/1998 tentang Penyelenggaraan Otonomi Daerah: Pengaturan, Pembagian, dan Pemanfaatan Sumberdaya Nasional yang Berkeadilan, serta Perimbangan Keuangan Pusat dan Daerah dalam Kerangka Negara Kesatuan Republik Indonesia. Jakarta, Indonesia.

Republik Indonesia. 2001. Keputusan Presiden Nomor 74 Tahun 2001 tentang Tata Cara Penyelenggaraan Pemerintahan Daerah. Jakarta, Indonesia.

Rosseptalia, Rima. 2006. "Pengaruh Pengetahuan Dewan tentang Anggaran terhadap Pengawasan Keuangan Daerah dengan Variabel Moderator Partisipasi Masyarakat dan Transparansi Kebijakan Publik”. Skripsi. Yogyakarta: Universitas Islam Indonesia.

Sopanah, dan Mardiasmo. 2003. "Pengaruh Partisipasi Masyarakat dan Transparansi Kebijakan Publik terhadap Hubungan antara Pengetahuan Dewan tentang Anggaran dengan Pengawasan Keuangan Daerah". Simposium Nasional Akuntansi VI, hal. 1160-1173.

Werimon, Simson. 2005. "Pengaruh Partisipasi Masyarakat dan Transparansi Kebijakan Publik terhadap Hubungan antara Pengetahuan Dewan tentang Anggaran dengan Pengawasan Keuangan Daerah (APBD)". Tesis. Semarang: Universitas Diponegoro.

Yudono, Bambang. 2002. Optimalisasi Peran DPRD dalam Penyelenggaraan Pemerintah Daerah,[Online]. Didapatkan: http://www.bangda.depdagri.go.id [20 Oktober 2011]. 


\section{LAMPIRAN}

\section{Hasil Uji Normalitas}

One-Sample Kolmogorov-Smirnov Test

\begin{tabular}{|cc|c|}
\hline & & $\begin{array}{c}\text { Unstandardiz } \\
\text { ed Residual }\end{array}$ \\
\hline Normal & Mean & 41 \\
Parameters(a,b) & Std. Deviation &, 0000000 \\
Most Extreme & Absolute &, 28026348 \\
Differences & Positive &, 140 \\
& Negative &, 135 \\
Kolmogorov-Smirnov Z &,- 140 \\
Asymp. Sig. (2-tailed) &, 896 \\
\hline \multicolumn{2}{|c|}{ Asyma } \\
\hline
\end{tabular}

a Test distribution is Normal.

b Calculated from data.

\section{Hasil Uji Autokorelasi}

Model Summary(b)

\begin{tabular}{|l|r|r|r|r|r|}
\hline Model & $\mathrm{R}$ & $\mathrm{R}$ Square & $\begin{array}{c}\text { Adjusted } \\
\text { R Square }\end{array}$ & $\begin{array}{c}\text { Std. Error of } \\
\text { the Estimate }\end{array}$ & $\begin{array}{c}\text { Durbin- } \\
\text { Watson }\end{array}$ \\
\hline 1 &, $471(\mathrm{a})$ &, 222 &, 202 &, 28383 & 1,691 \\
\hline
\end{tabular}

a Predictors: (Constant), PENGETAHUAN ANGGOTA DPRD TENTANG ANGGARAN

b Dependent Variable: PENGAWASAN KEUANGAN DAERAH

\section{Hasil Uji Heteroskedastisitas}

\section{Coefficients(a)}

\begin{tabular}{|c|c|c|c|c|c|c|}
\hline \multirow[t]{2}{*}{ Model } & & \multicolumn{2}{|c|}{$\begin{array}{c}\text { Unstandardized } \\
\text { Coefficients }\end{array}$} & \multirow{2}{*}{$\begin{array}{c}\text { Standardized } \\
\text { Coefficients } \\
\text { Beta } \\
\end{array}$} & \multirow{2}{*}{$\frac{t}{B}$} & \multirow{2}{*}{$\begin{array}{c}\text { Sig. } \\
\text { Std. Error }\end{array}$} \\
\hline & & $B$ & Std. Error & & & \\
\hline 1 & $\begin{array}{l}\text { (Constant) } \\
\text { PENGETAHUAN } \\
\text { ANGGOTA DPRD }\end{array}$ & 1,070 & ,736 & & 1,453 & , 154 \\
\hline & $\begin{array}{l}\text { TENTANG } \\
\text { ANGGARAN }\end{array}$ &,- 174 & 149 &,- 184 & $-1,168$ & 250 \\
\hline
\end{tabular}

a Dependent Variable: AbsUt

HASIL UJI ANALISIS REGRESI SEDERHANA

Model Summary

\begin{tabular}{|l|r|r|r|r|}
\hline Model & $\mathrm{R}$ & R Square & $\begin{array}{c}\text { Adjusted } \\
\text { R Square }\end{array}$ & $\begin{array}{r}\text { Std. Error of } \\
\text { the Estimate }\end{array}$ \\
\hline 1 &, $471(\mathrm{a})$ &, 222 &, 202 &, 28383 \\
\hline
\end{tabular}

a Predictors: (Constant), PENGETAHUAN ANGGOTA DPRD TENTANG ANGGARAN 
Coefficients(a)

\begin{tabular}{|c|c|c|c|c|c|c|}
\hline \multirow[b]{2}{*}{$\begin{array}{l}\text { Mode } \\
1\end{array}$} & & \multicolumn{2}{|c|}{$\begin{array}{l}\text { Unstandardized } \\
\text { Coefficients }\end{array}$} & \multirow{2}{*}{$\begin{array}{c}\text { Standardize } \\
d \\
\text { Coefficients } \\
\text { Beta }\end{array}$} & \multirow[b]{2}{*}{$B$} & \multirow{2}{*}{$\begin{array}{l}\text { Sig. } \\
\text { Std. } \\
\text { Error }\end{array}$} \\
\hline & & B & $\begin{array}{l}\text { Std. } \\
\text { Error }\end{array}$ & & & \\
\hline 1 & $\begin{array}{l}\text { (Constant) } \\
\text { PENGETAHUAN }\end{array}$ & ,843 & 1,156 & & ,729 & ,470 \\
\hline & $\begin{array}{l}\text { ANGGOTA DPRD } \\
\text { TENTANG } \\
\text { ANGGARAN }\end{array}$ & 781 & ,234 & 471 & 3,339 & ,002, \\
\hline
\end{tabular}

a Dependent Variable: PENGAWASAN KEUANGAN DAERAH

HASIL UJI MODERATED REGRESSION ANALYSIS (MRA) Model Summary

\begin{tabular}{|l|c|r|r|r|}
\hline Model & $\mathrm{R}$ & $\mathrm{R}$ Square & $\begin{array}{c}\text { Adjusted } \\
\text { R Square }\end{array}$ & $\begin{array}{c}\text { Std. Error of } \\
\text { the Estimate }\end{array}$ \\
\hline 1 &, $725(\mathrm{a})$ &, 526 &, 458 &, 23399 \\
\hline
\end{tabular}

a Predictors: (Constant), MODERATX1X3, MODERATX1X2, PENGETAHUAN ANGGOTA DPRD TENTANG ANGGARAN, TRANSPARANSI KEBIJAKAN PUBLIK, PARTISIPASI MASYARAKAT

Coefficients(a)

\begin{tabular}{|c|c|c|c|c|c|c|}
\hline \multirow[b]{2}{*}{ Mode } & & \multicolumn{2}{|c|}{$\begin{array}{l}\text { Unstandardized } \\
\text { Coefficients }\end{array}$} & \multirow{2}{*}{$\begin{array}{c}\text { Standardized } \\
\text { Coefficients } \\
\text { Beta }\end{array}$} & \multirow[b]{2}{*}{ B } & \multirow{2}{*}{$\begin{array}{c}\text { Sig. } \\
\text { Std. Error }\end{array}$} \\
\hline & & B & Std. Error & & & \\
\hline \multirow[t]{7}{*}{1} & (Constant) & $-110,661$ & 30,449 & & $-3,634$ & ,001 \\
\hline & & 22050 & 6120 & 12856 & 3714 & $0 \cap 1$ \\
\hline & & 22,950 & 6,129 & 13,856 & $3, / 44$ & 1001, \\
\hline & $\begin{array}{l}\text { PARTISIPASI } \\
\text { MASYARAKAT }\end{array}$ & 13,781 & 5,458 & 18,351 & 2,525 & ,016 \\
\hline & $\begin{array}{l}\text { TRANSPARANSI } \\
\text { KEBIJAKAN PUBLIK }\end{array}$ & 13,279 & 3,757 & 24,574 & 3,535 & 001 \\
\hline & MODERATX1X2 & $-2,727$ & 1,098 & $-21,106$ & $-2,483$ & ,018 \\
\hline & MODERATX $1 X 3$ & $-2,657$ & ,755 & $-24,563$ & $-3,521$ & 001 \\
\hline
\end{tabular}

a Dependent Variable: PENGAWASAN KEUANGAN DAERAH 